\title{
Comparative Investigation of Difference between Ownership Structure and Cost of Capital in Capitalized and Levered Companies of Tehran Stock Exchange (TSE)
}

\author{
Saeid Jabbarzadeh Kangarlouei ${ }^{1, *}$, Sajad Abbaszadeh ${ }^{2}$, Morteza Motavassel ${ }^{3}$ \\ ${ }^{1}$ Department of Accounting, Islamic Azad University, Orumieh Branch, Orumieh Iran \\ ${ }^{2}$ M. A. Student in Accounting, Islamic Azad University, Hamedan Branch, Iran \\ ${ }^{3}$ M.A. student in Accounting, Islamic Azad University, West Azerbaijan Science and Research Branch, Iran
}

\begin{abstract}
The purpose of this study is the comparative investigation of difference between ownership structure and cost of capital in capitalized and levered companies of TSE. The population of this study is 81 listed companies in the TSE during the period of 2003 to 2009. Studied variables in this study include ownership structure as independent variable that it is divided into two variables, type of ownership and the degree of ownership concentration. Ownership type in this study is divided into four classes including governmental, institutional, individual and private ownership. In addition, Hrfyndal-Hyrshmn index (HHI) is used for calculation of ownership concentration ratio. Cost of capital is considered as dependent variable. Finally, the hypotheses are tested using Multivariate Analysis of Variance (Manova). Based on the research results, governmental and private institutional ownership increase average cost of capital in levered companies more than capitalized companies and private individual ownership results in reduction of average cost of capital in levered companies more than capitalized companies. Also, based on the research results, concentration of ownership reduces of cost of capital in capitalized companies more than levered companies, however, diffused ownership increases average cost of capital in capitalized companies than levered companies.
\end{abstract}

Keywords Ownership Structure, Cost of Capital, Capitalized and Levered Companies

\section{Introduction}

Corporate financing decisions are quite complex processes and existing theories can at best explain only certain facts of the diversity and complexity of financing choices (Margaritis and Psillaki, 2009). Financial decision-making is a process leading to efficient and effective resolution. One of the ways to maximize stockholders wealth as important role of financial manager is taking optimal decisions to increase firm's wealth. Cost of capital is a benchmark for investment decisions, creating optimal capital structure and performance measurement (Davari et al., 2005). Weak corporate governance not only increases cost of capital but also mitigates firm's competitive advantage as a result of cost of capital increasing (kermani, 2008). Cost of capital has two dimensions, internal and external. Internally, cost of capital is used to evaluate securities and firm's performance. External- ly, cost of capital has a key role in investment decisions and optimal level of capital (Osmani, 2002).

On the other hand, the subject of ownership and man-

* Corresponding author:

Dr_jabbarzadeh@yahoo.com (Saeid Jabbarzadeh Kangarlouei)

Published online at http://journal.sapub.org/ijfa

Copyright (C 2012 Scientific \& Academic Publishing. All Rights Reserved agement separation and its effect on organizations performance has been a subject of scrutiny. This separation leads to agency cost theory, the idea that the interests of the company's managers and its shareholders are not perfectly aligned (Margaritis and Psillaki, 2009). Corporate governance and ownership structure are mechanisms to reduce agency cost. It is expected that every change in corporate governance structure lead to changes in firm's performance and strategy and also agency cost increase or decrease. Producing direct evidence on the magnitude of agency costs, however, is difficult because the proposition that inefficiency increases as the degree of shareholder dispersion increases. The reason is that the ownership structure of the firm as well as other corporate control mechanisms is endogenous. It will change as long as there is profit to be made from eliminating managerial inefficiency. In equilibrium, ownership structure may vary across firms, but the degree of managerial inefficiency will not. Although this conclusion is qualified by the existence of transaction costs, it is usually argued that these costs are low for public corporations since their shares can be traded at low cost. These characteristics may be related to the potential for managerial inefficiency, but firm performance does not depend on the degree of dispersion of the equity ownership structure (Gorton and Schmid, 1999). 

and Cost of Capital in Capitalized and Levered Companies of Tehran Stock Exchange (TSE)

Other aspect of ownership structure is concentration of ownership, the state in which significant shares of stock is belonged to few stockholders (Etemadi et al., 2009). The main advantage of concentration of ownership is to monitor manager's performance. However, this has a disadvantage of liquidity reduction and risk augmentation. In contrast, diffusion of ownership has advantage of liquidity accumulation and efficient resources allocation. However, this situation gives managers to act contrary to stockholders benefits (Jensen and Meckling, 1976).

\section{Literature Review}

Singh and Nejadmalayeri (2004) report that internationally diversified firms support higher level of debt financing that directly results in reduction of overall cost of capital despite higher equity risk. More significantly, they find that even after controlling for the effects of the degree and composition of debt financing, equity risk, firm size, managerial agency costs, and asset structure, higher degree of international diversification results in lower overall- combined debt and equity-cost of capital.

Santanu (2010) in an investigation documents that empirical evidence on Indian companies suggests that after controlling for major determinants like profitability, risk, tangibility, growth and size, debt has a positive relationship with the concentrated shareholding and a negative relationship with the diffuseness of shareholding and profitability and ownership structure explains capital structure but not the vice versa.

García-Meca and Sánchez-Ballesta (2011) investigated the relationship between ownership structure and forecast accuracy in Spain. Their results show a positive and significant influence of bank ownership on analyst forecast accuracy, which suggests that bank ownership leads to closer monitoring of management and a reduction in analyst forecast errors. However, they show that the presence of large shareholders and insiders in the ownership structure of the firm does not significantly affect the accuracy of financial analysts.

Margaritis and Psillaki (2009) explored the relationship between capital structure, equity ownership and firm performance. Their results show that the effect of leverage on firm performance as well as the reverse causality relationship while controlling for the effects of ownership structure and ownership type. They also find that more concentrated ownership is generally associated with more debt in the capital structure. However, they find no evidence that ownership type has an effect on leverage choices.

Barry et al. (2010) studied the relationship between ownership structure and risk in publicly held and privately owned banks and find that ownership structure is significant in explaining risk differences but mainly for privately owned banks. Also, they show that a higher equity stake of individuals/ families or banking institutions is associated with a decrease in asset risk and default risk. In addition, institu- tional investors and non-financial companies impose the riskiest strategies when they hold higher stakes. For publicly held banks, changes in ownership structure do not affect risk taking. However, higher stakes of banking institutions in publicly held banks are associated with lower credit and default risk.

Céspedes et al. (2009) indicate a positive relation between leverage and ownership concentration, when losing control becomes an issue. In addition, they show a positive relation between leverage and growth. Moreover, their study reports that other determinants that do not proxy for control rights are consistent with previous findings. Firms that are larger, have more tangible assets, and are less profitable are also more levered.

Lin et al. (2011) using a large sample of U.S. firms during the 1994-2002 period, find that the shadow value of external funds is significantly higher for companies with a wider insider control-ownership divergence, suggesting that companies whose corporate insiders have larger excess control rights are more financially constrained. They also show that the effect of insider excess control rights on external finance constraints is more pronounced for firms with higher degrees of informational opacity and for firms with financial misreporting, and is moderated by institutional ownership. In addition, their results show that the agency problems associated with the control-ownership divergence can have a real impact on corporate financial and investment outcomes.

Henry (2009) investigating the relationship between agency costs, ownership structure and corporate governance compliance show that the influence of voluntary governance compliance on agency costs is independent of firm ownership structure.

Lin et al. (2010) using a new, hand-collected data set on corporate ownership and control of 3,468 firms in 22 countries during the 1996-2008 period, find that the cost of debt financing is significantly higher for companies with a wider divergence between the largest ultimate owner's control rights and cash-flow rights. Their results suggest that potential tunnelling and other moral hazard activities by large shareholders are facilitated by their excess control rights. These activities increase the monitoring costs and the credit risk faced by banks and, in turn, raises the cost of debt for the borrower.

Elyasiani et al. (2010) investigating the relationship between institutional ownership stability and the cost of debt found these results: First, there is a robust negative relationship between the cost of debt and institutional ownership stability. Second, institutional ownership stability plays a bigger role in determining the cost of debt, than the institutional ownership level commonly used in the literature. Third, institutional ownership stability affects the cost of debt to a greater extent for firms that are subject to more severe information asymmetry and greater agency costs of debt.

Boubakri and Ghouma (2010) find strong evidence that ultimate ownership (i.e., the voting/cash-flow rights wedge) and family control have a positive and significant effect on 
bond yield-spreads, and a negative and significant effect on bond ratings. Control in the hands of widely held financial firms has a positive effect on bond ratings only, while State control has no effect on either bond yield-spreads or ratings. They also find that a higher protection of debt holders' rights generally reduces bond yield-spreads and increases bond ratings. Their results additionally show that, for both bondholders and rating agencies, the enforcement of debt laws is crucially important. Finally, they document a negative effect of debt covenants on debt costs when there is a high expropriation risk and poor creditor rights protection.

$\mathrm{Lu}$ et al. (2012) find that compared with Chinese stateowned firms, non-state-owned firms have a greater propensity to hold significant ownership in commercial banks. They also find that among non-state-owned firms, those that hold significant bank ownership have lower interest expenses, and are less likely to increase cash holdings but more likely to obtain short-term loans when the government monetary policy is tight.

HasasYeganeh and Sharyari (2010) investigated the relationship between ownership concentration and conservatism based on financial information of TSE during the period of 2002 to 2006 . They find that controlling the variables of size, growth; there is a negative significant relationship between ownership concentration and conservatism. This result is consistent with the self-benefit, pooling strategies and against with active monitoring hypothesis.

Muhammadi et al. (2009) investigated the effect of ownership structure on firm's value and return in the firms listed in TSE and find a positive linear relationship between ownership concentration and firms return. In addition, they find no relationship between ownership concentration and firm's value. On the other hand, the results of ownership type effect show that there is a reverse relationship between individual, private and corporate ownership and stock return.

\section{Methodology and Data Collection}

Since in this study the difference between ownership structure and cost of capital is investigated, the method of study is descriptive-correlation. On the other hand, considering that the difference between ownership structure and cost of capital in two groups is compared, the study is causal-comparative research. The population of the study consists of the listed firms in TSE for the period of 2003 to 2009. Sample firms must have following characteristics:

1-Financial information must be available.

2-Fiscal year must be ended at the end of year.

3-Must not change their fiscal year during studied period

4-Must not be investment and brokerage firm.

5 -Must have listed for 5 years before the beginning of study period.

6-Transactions intervals must not be more than 6 month.

As a result of these characteristics, a sample of 81 firms is obtained. In order to collect research data, TSE database is used and then the ratios using collected data for each firm and year is calculated using Excel software. Finally, SPSS software is used to test hypotheses using Multivariate Analysis of Variance (Manova).

\section{Hypotheses Development}

The main question of this study is: is there a significant difference between ownership structure and cost of capital in two groups of levered and capitalized firms in TSE? According to this question and the studies conducted before, in this study one main hypothesis and two sub-hypotheses are prepared as following:

Main hypothesis: There is a significant difference between ownership structure and cost of capital in two groups of levered and capitalized firms in TSE.

Sub-hypothesis 1: There is a significant difference between ownership type and cost of capital in two groups of levered and capitalized firms in TSE.

Sub-hypothesis 1-1: There is a significant difference between governmental ownership and cost of capital in two groups of levered and capitalized firms in TSE.

Sub-hypothesis 1-2: There is a significant difference between institutional ownership and cost of capital in two groups of levered and capitalized firms in TSE.

Sub-hypothesis 1-3: There is a significant difference between individual ownership and cost of capital in two groups of levered and capitalized firms in TSE.

Sub-hypothesis 1-4: There is a significant difference between private ownership and cost of capital in two groups of levered and capitalized firms in TSE.

Sub-hypothesis 2: There is a significant difference between ownership concentration and cost of capital in two groups of levered and capitalized firms in TSE.

\section{Variables Definition}

\section{Dependent variable:}

Ownership structure: in this research, ownership structure is divided into two variables of ownership type and the degree of ownership concentration.

Ownership ratio: is indicator of ownership ratio in different sectors which is applied to each firm. This variable is divided into four sector of governmental, private, institutional and individual ownership. Following defines each of variables (Muhammadi et al., 2009).

Firm with governmental ownership: a firm that more than 50 percent of its stock belongs to government and or other governmental firms and sectors.

Firm with institutional ownership: a firm that the biggest owner is a non-governmental legal entity.

Firm with individual ownership: a firm that the biggest owner is individual entity.

Firm with private ownership: a firm that the biggest owner is a non-governmental legal entity or individual entity (institutional ownership and individual ownership). 
Ownership concentration: Ownership concentration refers to the amount of stock owned by individual investors and large-block shareholders, less stockholder, more concentration. In this study, Hrfyndal-Hyrshmn index (HHI) is used for calculation of ownership concentration ratio. This index is calculated by squaring the sum of shares belonged to firm's stockholders. This index increases along with increasing the level if ownership concentration and in a circumstances that the whole of shares is belonged to one person, gets the most value of 10.000 and in a circumstances of ownership structure diffusion, all of stock holders has the same share, HHI gets the least value of 10000/N.

$\mathrm{HHI}$ is calculated as following:

$$
\mathrm{HHI}=\sum_{\mathrm{i}=1}^{n}\left(\frac{p_{i}}{p} \times 100\right)^{2}
$$

Dependent variable:

Cost of capital (debt and equity cost) is minimum of return rate which firms must obtain to satisfy investors expected return. Cost of debt is calculated through interest cost in year $\mathrm{t}+1$ divided by average outstanding interest-bearing debts in the years of $t$ and $t+1$ and cost of equity is calculated through dividing net profit by market value of equity or earnings per share ratio on price per share (Rasaiyan and Hossieni, 2008).

Levered firms: firms that use debt to finance investment projects.

Capitalized firms: firms that use capital to finance investment projects (Jahankhani and Kanani, 2006).

According to firms financing policy, we can separate them into levered and capitalized firms. To do so, debt ratio is used which is calculated as following:

$$
\frac{\text { Total debts }}{\text { Total assets }}
$$

This ratio shows the percentage of cash holdings financed from debt. In this research, debt ratio is used as a measure to classify firms into capitalized and levered firms. Classification measure is in a way that first mean of this ratio is calculated for sample firms and then firm's actual debt is compared with calculated mean and firms with higher rate of mean is classified as levered firm and firms with lower ratio from mean is classified as capitalized firm.

\section{Empirical Results}

Sub-hypotheses 1: There is a significant difference between ownership type and cost of capital in two groups of levered and capitalized firms in TSE.

According to Table 1, governmental and institutional ownership, overall, for all the years result in cost of capital reduction than levered firms. These results may stem from that firms with governmental and institutional ownership is controlled by managers, contrast with firms with individual ownership. According to agency theory, managers are looking for their self-interest and since levered firms have characteristics like high cash holdings, cash flows, and dividend, they have debt capacity to borrow and have no financial constraint, contrast with capitalized firms (Ja- hankhani and Kanani, 2006). However, manager's excess use of debt as a result of having debt capacity for financing in these firms results in increasing cost of capital in levered firms than capitalized firms since the use of debt increases cost of capital because of risk augmentation and this is considered as hidden cost of debt financing. In other words, because debt brings certain fixed commitments (interest expense) for levered firm, these fixed commitments increases firms risk since firm failure to repay principal and interest of loan results in bankruptcy. In addition, levered firms with high free cash flows without favorable investment opportunity motivate mangers to misuse this opportunity trying to achieve their self-interest. However, family-controlled firms have less agency cost and since ownership is in control of owners not managers, every decision made in firm is according to manager and firm's interest. Therefore, owners use less financing methods with hidden costs.

On the other hand, if we want to conclude about private ownership, it can be inferred that institutional ownership leads to increase cost of capital in levered firms than capitalized firm and individual ownership leads to reduce cost of capital in levered firms than capitalized firm. To obtain exact results, the number of individual ownership and institutional ownership firms should be equal. On the whole, institutional ownership is good for capitalized firms and individual ownership is good for levered firms.

According to the results of Table 2, homogeneity of variance in above variables is accepted. Therefore, the use of MANOVA is available.

Table 1. Mean of cost of capital according to ownership type in capitalized and levered firms

\begin{tabular}{ccc|}
\hline $\begin{array}{c}\text { Ownership } \\
\text { type }\end{array}$ & $\begin{array}{c}\text { Mean of cost of capital } \\
\text { in capitalized firm }\end{array}$ & $\begin{array}{c}\text { Mean of cost of capi- } \\
\text { tal in levered firm }\end{array}$ \\
\hline governmental & 0.281 & 0.293 \\
\hline individual & 0.251 & 0.242 \\
\hline institutional & 0.258 & 0.301 \\
\hline
\end{tabular}

Table 2. Results of Leven test for total cost of capital according to ownership type in levered and capitalized firms

\begin{tabular}{|ccccc|}
\hline traces & Df2 & Df1 & \multicolumn{1}{c}{ F } & \multicolumn{1}{c}{ Sig. } \\
\hline Pillai's Trace & 78 & 2 & $7 / 74$ & 0.001 \\
\hline Wilks' Lambda & 78 & 2 & $7 / 74$ & 0.001 \\
\hline Hotelling's Trace & 78 & 2 & $7 / 74$ & 0.001 \\
\hline Roy's Largest Root & 78 & 2 & $7 / 74$ & 0.001 \\
\hline
\end{tabular}

According to Table 1 mean cost of capital held by government or private firms is less than cost of capital in levered and capitalized firm. In addition, mean cost of capital in capitalized firm held by individuals is more than cost of capital of levered firms held by individuals. According to Table 2, significance level shows that there is a significant difference between total capitals according to ownership type in levered and capitalized firm. In other words, since error level in this test for all years in intercept model is less than 0.05 so we can conclude that there is a significant difference between cost of capital according to ownership type in levered and capitalized firms. 
Sub-hypotheses 2:

There is a significant difference between ownership concentration and cost of capital in two groups of levered and capitalized firms in TSE.

We suppose ownership to be diffused if it is less than 1000 and concentrated if it is more than 1800 and finally moderate if it is between 1000 and 1800 according to HHI.

According to Table 4 concentrated ownership for all the years causes the reduction of cost of capital in capitalized firms than levered firms. However, diffused ownership for all the years causes to increase cost of capital in capitalized firms than levered firms. The reason may stem from the fact that diffused ownerships cause to increase mean cost of capital in capitalized firms than levered firms. In this regard, the benefits of managers will not go with the benefits of stockholders in tandem. Consequently, mangers decisions may increase only their own interest not stockholders. In other words, more ownership dispersion may lead to a weak impact of stockholders on firm's management because small stockholders have not motivation to monitor the manager and firm's performance. Monitoring the manager's behavior needs knowledge and data collection and process which needs to consume resources, however, it does not satisfy cost-benefit requirement. Therefore, in this situation owners have a weak impact on management decision for financing and manager looking for an easy way to finance, do it by capital increasing which is expensive (Jahankhani and
Kanani, 2006). This situation increases cost of capital in capitalized firms than levered firms. In addition, in firms with concentrated ownership, stockholders have direct control and monitoring on management behavior and managers cannot act against their interest. Therefore, firm's ownership has a direct impact on management decisions for financing. In this regard, managers will avoid financing from capital increasing leading cost of capital decreasing in capitalized firms than levered firms.

According to the results of Table 5, homogeneity of variance in variables is accepted. Therefore, the use of MANOVA is available.

According to Table 6, mean cost of capital in capitalized firm with concentrated ownership is less than cost of capital in levered firm with concentrated ownership. In addition, mean cost of capital in capitalized firm with moderate concentrated and diffused ownership is more than cost of capital of levered firms with moderate concentrated and diffused ownership. According to Table 6, significance level shows that there is a significant difference between total capitals according to ownership concentration in levered and capitalized firms. In other words, since error level in this test for all years in intercept model is less than 0.05 so we can conclude that there is a significant difference between cost of capital according to ownership concentration in levered and capitalized firms.

Table 3. The results of MANOVA for total cost of capital in terms of ownership type in levered and capitalized firms

\begin{tabular}{cccccc|c|c|}
\hline model & Dependent variable & Sum of squares & Degree of freedom & Square mean & \multicolumn{1}{c}{ F } & Sig. \\
\hline \multirow{2}{*}{ intercept } & Cost of capital & 6.15 & 1 & 6.15 & 831.66 & 0.001 \\
\cline { 2 - 8 } & Ownership type & 166.29 & 1 & 166.29 & 445.13 & 0.001 \\
\hline \multirow{2}{*}{ groups } & Cost of capital & 0.004 & 1 & 0.004 & 0.54 & 0.88 \\
\cline { 2 - 8 } & Ownership type & 0.364 & 1 & 0.364 & 0.97 & 0.47 \\
\hline
\end{tabular}

Table 4. Mean cost of capital according to the degree of ownership concentration in capitalized and levered firms

\begin{tabular}{|c|c|c|}
\hline Degree of ownership concentration & Mean cost of capital in capitalized firms & Mean cost of capital in levered firms \\
\hline concentrated & 0.272 & 0.293 \\
\hline maderate & 0.248 & 0.247 \\
\hline diffused & 0.274 & 0.257 \\
\hline
\end{tabular}

Table 5. Results of Leven test for total cost of capital according to ownership concentration in levered and capitalized firms

\begin{tabular}{|c|c|c|c|c|}
\hline traces & Df2 & Df1 & F & Sig. \\
\hline Pillai's Trace & 78 & 2 & 6.11 & 0.001 \\
\hline Wilks' Lambda & 78 & 2 & 6.11 & 0.001 \\
\hline Hotelling's Trace & 78 & 2 & 6.11 & 0.001 \\
\hline Roy's Largest Root & 78 & 2 & 6.11 & 0.001 \\
\hline
\end{tabular}

Table 6. The results of MANOVA for total cost of capital in terms of ownership concentration in levered and capitalized firms

\begin{tabular}{cccccc|c|c|}
\hline model & Dependent variable & \multicolumn{1}{c}{ Sum of squares } & Degree of freedom & Square mean & \multicolumn{1}{c}{ F } & Sig. \\
\hline \multirow{3}{*}{ intercept } & Cost of capital & 6.15 & 1 & 6.15 & \multicolumn{2}{c}{831.66} & 0.001 \\
\cline { 2 - 8 } & Ownership type & 205.95 & 1 & 205.95 & 307.46 & 0.001 \\
\hline \multirow{2}{*}{ groups } & Cost of capital & 0.004 & 1 & 0.004 & 0.54 & 0.46 \\
\cline { 2 - 8 } & Ownership type & 2.62 & 1 & 2.62 & 3.92 & 0.05 \\
\hline
\end{tabular}




\section{Results and Discussion}

The results of the study confirm our sub-hypotheses. Therefore, in all the cases, there is a significant difference between ownership structure and cost of capital in two groups of levered and capitalized firms showing that our main hypothesis is accepted.

The results of the first sub-hypothesis show that is it better that the main ownership of levered firms to be in the control of individual investors and also the main ownership of capitalized firms to be in the control of institutional or governmental investors. Because, levered firms controlled by institutional or governmental investors have more cost of capital than capitalized firms and levered firms controlled by individual investors have less cost of capital than capitalized firms. In the case of individual ownership, it can be said that there is significant difference, however, it can not be explained as to whether it leads to cost of capital increasing or decreasing.

The results of the second sub-hypothesis demonstrate that is it better that capitalized firms to have concentrated ownership and levered firms to have diffused ownership. Because concentrated ownership decreases cost of capital in capitalized firms than levered firms and diffused ownership increases cost of capital in capitalized firms rather than levered firms. These results are consistent with the studies of Santanu (2010) Cespedes et al. (2010).

\section{Research Limitations and Suggestions}

The main limitation of the study was to determine the type of firm's ownership, which is necessary to determine investors' type. Doing so, it was observed that investors type, on their own, have different classes and this process is recurred several times making this task difficult.

With respect to the results of the study, following remarks are suggested:

Levered firms controlled by institutional or governmental investors have more cost of capital than capitalized firms and levered firms controlled by individual investors have less cost of capital than capitalized. However, it is suggested that levered firm's ownership to be transferred to individual investors and capitalized firm's ownership to institutional or governmental investors.

Concentrated ownership decreases firms cost of capital in capitalized firms than levered firms and diffused ownership increases firms cost of capital in capitalized firms than levered firms. However, it is suggested that capitalized firms use less financing from equity capital and have diffused ownership and levered firms use more financing from equity capital and have concentrated ownership.

Since ownership structure affects cost of capital in capitalized and levered firms, it is suggested that investors consider ownership structure in financial statements analysis. In addition, it is suggested that analysts and managers do so.

\section{REFERENCES}

[1] Barry, A.T., Lepetit, L., Tarazi, A., 2010. Ownership structure and risk in publicly held and privately owned banks, Journal of Banking \& Finance. pp. 1327-1340

[2] Boubakri, N., Ghouma, H. 2010. Control/ownership structure, creditor rights protection, and the cost of debt financing: International evidence, Journal of Banking \& Finance, pp. 2481-2499

[3] Céspedes, J., González, M., A. Molina., C. 2009. Ownership and capital structure in Latin America, Journal of Business Research. pp. 248-254

[4] Davari, M., Abzari, M., Afrasyabi, P. 2005. The investigation of the relationship between firm's size and net profit growth and cost of capital in TSE, Center of calculation and information technology Asfahan University

[5] Etemadi, H. Babajani, J., Azar, A, Diani, Z. 2009. The effect of organizational culture, ownership concentration and ownership structure on the quality of financial information in firms listed in TSE, quarterly journal of Iran management, pp $59-85$

[6] Elyasiani, E., Jia, J., Mao, C., 2010. Institutional ownership stability and the cost of debt, Journal of Financial Markets, pp. $475-500$

[7] HasasYeganeh, Y., Shayari, A, 2010. The relationship between ownership concentration and conservatism in TSE, journal of social and human science research. pp. 72-94

[8] Henry, D., 2009, Agency costs, ownership structure and corporate governance Compliance, Pacific-Basin Finance Journal, pp. 24-46

[9] García-Meca, E., Sánchez-Ballesta, J. 2011. Ownership structure and forecast accuracy in Spain, Journal of International Accounting, Auditing and Taxation. pp. 73-82

[10] Gorton, G., Schmid, F. 1999. Corporate governance, ownership dispersion and efficiency: Empirical evidence from Austrian cooperative banking, Journal of Corporate Finance, pp. $119-140$

[11] Jahankhani. A., Kanani, M. 2006. Introduction of a model for determination of capital expenditure in TSE using accounting data, monthly scientific- research journal of Daneshvar behavior, ShahedUniversity, No. 17

[12] Jensen, G.R. Meckling, W. 1976. Theory of the firm: managerial behavior, agency cost and ownership structure, Journal off financial economics. Pp 305-306

[13] Kermani, A. 2008. Effect of ownership concentration on firm's performance in TSE, M.A theses, Shiraz University

[14] Lin, C., Mab, Y., Malatesta, P, Xuan, Y. 2010. Ownership structure and the cost of corporate borrowing, journal of Financial Economics, pp. 1-23

[15] Lin, C., Mab, Y., Xuan, Y. 2011. Ownership structure and financial constraints: Evidence from a structural estimation, Journal of Financial Economics, pp. 416-431

[16] Lu, Z., Zhu, J., Zhang., W. 2012. Bank discrimination, holding bank ownership, and economic consequences: Evidence from China, Journal of Banking \& Finance, pp. 341-354 
[17] Margaritis, aD., Psillaki, M. 2009. Capital structure, equity ownership and firm performance, Journal of Banking \& Finance. pp 621-632

[18] Muhammadi, SH., AlibafAsl, M, 2009, investigation of the impact of ownership structure (central and combination) on return and firms value listed in TSE, financial research, No 28, pp 69-69

[19] Osmani, G. 2002. Determination of cost of capital models and influential factors on it, doctorial theses, Alameh Tabatabaee University
[20] Santanu K. G. 2010. Capital Structure - Does Ownership Structure Matter? Theory and Indian Evidence. http:/ /ssrn.com/abstract $=1618747$

[21] Singh, M., Nejadmalayeri, A. 2004. Internationalization, capital structure, and cost of capital: evidence from French corporations, J. of Multi. Fin. Manag. pp. 153-169

[22] Rasaiyan, A., Hossieni, V. 2008. The relationship between the quality of discretionary accruals and cost of capital in Iran, auditing and accounting review, pp. 68-82 